\title{
MULTI ATTRIBUTE DECISION MAKING FOR MOBILE PHONE
} SELECTION

\author{
Sandeepak Saket ${ }^{1}$, Vidyapati Purbey ${ }^{2}$, Jagadish $^{3}$, Amitava Ray ${ }^{4}$ \\ ${ }^{1}$ B.Tech, Mechanical Engineering, NIT Silchar, Assam, India \\ ${ }^{2}$ B.Tech, Mechanical Engineering, NIT Silchar, Assam, India \\ ${ }^{3}$ Assistant Professor, Mechanical Engineering, NIT Silchar, Assam, India \\ ${ }^{4}$ Assistant Professor, Mechanical Engineering, NIT Silchar, Assam, India
}

\begin{abstract}
In current scenario the role of mobile is essential for the new generation people and for new system. A systematic and efficient approach towards selection of mobile is necessary for a commons people. To fulfil need of customer in the mobile areas is challenging task for the designer. The objective of this paper is to selecting the suitable mobile by taking cost as constraint. In this paper multi attribute decision making method (MCDM) i.e. QFD approach has been used for selection of appropriate mobile to the commons people. In selection of the mobile people find difficulties due to multiple attributes/criteria. In this study, the customer requirements are taken as input and appropriate technical requirements has been computed using Quality Functional Deployment (QFD). The validation of the proposed methodology is illustrated by a real life case study.
\end{abstract}

Keywords: QFD, MCDM, Mobile Selection

\section{INTRODUCTION}

QFD is the customer driven tool in implementing TQM (total quality management) And it provide means of translating customer requirement to technical requirement for each stage of the engineering application. In present scenario application of the mobile play an important role to connect the people throughout the world. In present scenario due to the competition all mobile company are bringing many varieties of mobile into the market within less time with addition of good feature from one version to another and at high cost as well as at low cost. In present scenario most of the industry focusing on profit of their business industries are increasing feature day to day so cost is also increasing this make suffer to poor people hence which necessities in the implementation of methodology in selecting an optimal mobile among several choice for the middle class peoples. Which makes present generation common people difficult in selecting the appropriate mobile among the verities of available choice even for the designer to make the mobile to the customer satisfaction is a difficult task and for all the mobile manufacturing industries. Selection of the common people is MCDM (multi criteria decision making) problem for entire mobile industry which involves many input/output criteria and alternative.

Many researcher has been worked in selection area like Bhattacharya et al. (2005) integrating AHP with QFD for robot selection under requirement perspective, Wang and Chen (2012) using QFD for collaborative product design and optimal selection of module mix, Prasad and Chakraborty (2103) a quality function deployment based model for material selection, Rao R.V.(2006) a material selection model using graph theory and matrix approach, Rajesh and malliga (2013) supplier selection based on AHP QFD methodology, M. Bevilacqua et al. (2006) a fuzzy QFD approach to supplier selection, journal of purchasing and supply management, S.H. Ha, and Krishnan (2008) a hybrid approach to supplier selection for the maintenance of competitive supply chain, expert system with application. In mobile phone many researcher like Isiklar and Buyukozkan (2007) using a multicriteria decision making approach to evaluate mobile phone alternatives, Zheng and pull (2007) Improving mobile service design a QFD approach, Xin et al. (2013) robust passive auto focus system for mobile phone camera application, O. Jiyong et al. (2013) selective generation of gabor feature for fast face recognition on mobile device, Jaeminchun (2011). A method for searching photos on a mobile phone by using the fishey view technique, ElieKhoury et al. (2013) Bi- model biometric authentication on mobile phone in challenging conditions, W. Chianghong et al. (2010) Taiwanese 3G mobile phone demand forecasting by SVR with hybrid evolutionary algorithms, Eekanbayraktar et al. (2012) measuring the efficiency of customer satisfaction and loyalty for mobile phone brand with DEA.

From the literature review it is found that, no researcher has been worked in the area of mobile selection for the common people using QFD approach. In this paper local survey has 
been carried out at NIT Silchar place Fakir Tilla for collecting the customer requirements for QFD matrix.

The following section explained in this paper as follows: Section.Error! Bookmark not defined., Section. 3 discussion and detailed case study i.e. validation of case study is discussed, Section. 4 result and discussion has been discussed. Finally reference has been explained in last section.

\section{HOUSE OF QUALITY}

The primary planning tool used in QFD is the house of quality. The house of quality translates the voice of the customer into design requirements that meet specific target values and matches that against how an organization will meet those requirements. Many managers and engineers consider the house of quality to be the primary chart in quality planning.

The structure of QFD can be thought of as a framework of a house, as shown in Fig- 1

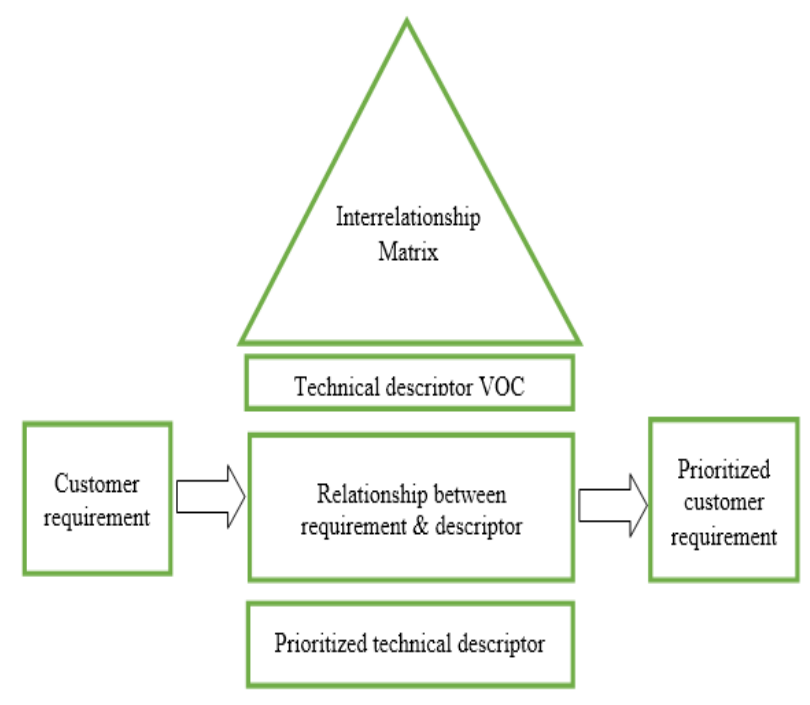

Fig- 1 House of quality

The parts of the house of quality are described as follows:

1. The exterior walls of the house are the customer requirements. On the left side is a listing of the voice of the customer, or what the customer expects in the product. On the right side are the prioritized customer requirements, or planning matrix. Listed are items such as customer benchmarking, customer importance rating, target value, scale-up factor, and sales point.

2. The ceiling, or second floor, of the house contains the technical descriptors. Consistency of the product is provided through engineering characteristics, design constraints, and parameters.
3. The interior walls of the house are the relationships between customer requirements and technical descriptors. Customer expectations (customer requirements) are translated into engineering characteristics (technical descriptors).

4. The roof of the house is the interrelationship between technical descriptors. Trade-offs between similar or conflicting technical descriptors is identified.

5 The foundation of the house is the prioritized technical descriptors. Items such as the technical benchmarking, degree of technical difficulty, and target value are listed.

\subsection{Building a House of Quality}

Step 1: List Customer Requirements (WHATs)

Step 2: List Technical Descriptors (HOWs)

Step 3: Develop a Relationship Matrix between WHATs and HOWs

Step 4: Develop an Interrelationship Matrix between HOWs

Step 5: Competitive Assessments

\subsection{QFD Approach Concept of QFD Process for}

\section{Mobile Selection}

In the mobile service industry the QFD approach can be implemented throughout mobile service design and development stages a generic framework for application of QFD in the mobile service is given in

Fig- 2

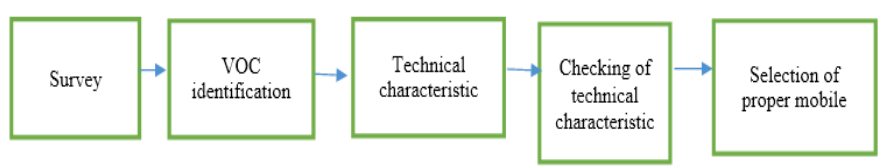

Fig- 2 Generic framework for QFD application in mobile service industry

In (

Fig- 2) there are five stages for mobile service development and deployment process. The five stages are explained in details as fallows.

- Survey: In the first step survey is conducted among the various people of villager near the nit and find out the view of villager toward the mobile of any company and find out which quality of mobile give more satisfaction to villager.

- VOC Identification: Voice of the Customer (VOC) is a term that describes your customer's feedback about their experiences with and expectations for your products or services. VOC is a multi-source information tool that focuses on customer needs, expectations, and product improvement. The voice of the customer is best heard as an ongoing conversation. The key to creating an effective VOC 
program is to gather and use information in a timely way that helps you to improve. Organizations often have multiple touch points with the customer that occur all across the organization, including sales, support, warranty, and accounting interactions. Due to VOC we are able to find out the following thing:

$\circ$ The needs and wants of customers

- The relative importance of features and benefits associated with product

o The expectations and promises that are both fulfilled and unfulfilled by product or service

- What customers need for increased satisfaction?

- Technical characteristic: Those characteristics of equipment that pertain primarily to the engineering principles involved in producing equipment possessing desired military characteristics; e.g. for electronic equipment, technical characteristics include such items as circuitry as well as types and arrangement of components. Cell phone technical specifications are the main technologies that the phone employs to perform such functions as receiving a signal, accessing and downloading data or accepting different software applications. The expression also applies to basic information such as cell phone dimensions, weight, etc. some of the general technical characteristic is as follows:
a) Loudspeaker
b) Memory/space
c) Bluetooth
d) Battery

- Checking of technical characteristics in mobile: In this step we check proper software and hardware in the mobile which fulfil the village need.

- Selection of proper mobile: This is the final step for mobile selection for villager in this step we find out the best mobile company among the shortlisted mobile company which give more satisfaction level to the villager according to their need.

\section{A CASE STUDY}

In this research select three mobile like Nokia, Samsung, and Micromax has been considered as a criteria and cost for this mobile is kept as constant for our mobile selection problem is as shown in

Fig- 3
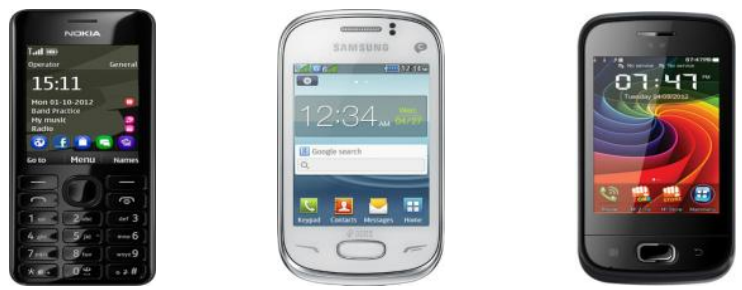

Nokia 206
Samsung Rex 70 S380
Micromax X446
Fig- 3 Mobile Alternatives

\subsection{Proposed Methodology}

In this step detail steps of QFD approach for selecting mobile is as follows:

\section{Step1: Customer and technical requirement}

In this step from the survey seven criteria is collected for the analysis the conversion of customer to technical is shown below in HOQ. Table- 1

Table- 1: Customer and technical requirement

\begin{tabular}{|l|l|}
\hline Customer requirement & Technical requirement \\
\hline High quality image (CR1) & High resolution (TR1) \\
\hline $\begin{array}{l}\text { Good visibility of video or } \\
\text { picture (CR2) }\end{array}$ & Display size (TR2) \\
\hline Long battery backup (CR3) & Power consumption(TR3) \\
\hline Internal feature (CR4) & Internal feature (TR4) \\
\hline Data transfer (CR5) & Bluetooth (TR5) \\
\hline More storage space (CR6) & Internal memory (TR6) \\
\hline Easy to operate (CR7) & Easy key button function (TR7) \\
\hline More audio volume (CR8) & Loudspeaker (TR8) \\
\hline
\end{tabular}

\section{Step2: Generation of relationship matrix}

In this step relationship matrix has been carried out between customer requirement and technical requirement to achieve this criteria weights has been taken in consideration for completing the relationship matrix customer weights taken for customer requirement high quality image (CR1), good visibility of video or picture(CR2), long battery backup (CR3), internal feature (CR4), data transfer (CR5), more storage space (CR6), easy to operate(CR7), more audio volume(CR8) as shown below in Table- 2

Table- 2: Priority of customer requirement

\begin{tabular}{|l|l|}
\hline Customer requirement & Important priority \\
\hline High quality image & 5 \\
\hline Good visibility & 3 \\
\hline Long battery backup & 5 \\
\hline Internal feature & 3 \\
\hline Data transfer & 4 \\
\hline More storage space & 2 \\
\hline Easy to operate & 3 \\
\hline More audio volume & 5 \\
\hline
\end{tabular}

Step3: Absolute technical criteria weight calculation In this step calculation of weight age for technical requirement is calculated and tabulated in Table- 3 
Table- 3: House of quality

\begin{tabular}{|c|c|c|c|c|c|c|c|c|c|c|}
\hline \multirow{2}{*}{ CR } & \multicolumn{7}{|c|}{$\begin{array}{l}\text { Prio- } \\
\text { rity }\end{array}$} & \multicolumn{7}{|c|}{ Technical Requirement } & \multirow{2}{*}{ W } \\
\cline { 4 - 10 } & & 1 & 2 & 3 & 4 & 5 & 6 & 7 & 8 & \\
\hline 1 & 5 & 9 & 1 & 3 & & & & & & 65 \\
\hline 2 & 3 & 3 & 9 & 3 & & & & & & 45 \\
\hline 3 & 5 & & 1 & 9 & & & & & 1 & 55 \\
\hline 4 & 3 & & & & 9 & & & & & 27 \\
\hline 5 & 4 & & & & 1 & 9 & & & & 40 \\
\hline 6 & 2 & & & & & & 9 & & & 18 \\
\hline 7 & 3 & & & & & & & 9 & & 27 \\
\hline 8 & 5 & & & & & & & & 9 & 45 \\
\hline W & & 54 & 37 & 69 & 31 & 36 & 18 & 27 & 45 & \\
\hline$\% \mathrm{~W}$ & & 17 & 11.6 & 21.7 & 9.7 & 11.3 & 5.6 & 8.5 & 14.1 & \\
\hline
\end{tabular}

*Strong point- $9, *$ Weak point- $3, *$ Very weak- 1

Step 4: Ranking of technical requirement weightage

In this step ranking of technical requirement weights is carried out as shown in Table- 4 .

Table- 4: Rank of technical weights

\begin{tabular}{|c|c|c|}
\hline $\begin{array}{c}\text { Technical } \\
\text { characteristic }\end{array}$ & Weights & Rank \\
\hline TR1 & 54 & 2 \\
\hline TR2 & 37 & 4 \\
\hline TR3 & 69 & 1 \\
\hline TR4 & 31 & 6 \\
\hline TR5 & 36 & 5 \\
\hline TR6 & 18 & 8 \\
\hline TR7 & 27 & 7 \\
\hline TR8 & 45 & 3 \\
\hline
\end{tabular}

Step5: Comparison of technical requirement weights with different mobile brand

In this step comparison of technical requirement $1^{\text {st }}$ obtained from the phase-1 QFD with different brands of mobile available in market. In this study three branded mobile has been taken like Nokia, Samsung, and Micromax.

The comparison in result is shown in Table- 5 and in Colum chart also shown in Fig- 4

Table- 5: weight score of different brands of mobile

\begin{tabular}{|c|c|c|c|c|}
\hline $\begin{array}{c}\text { Technical } \\
\text { requirement }\end{array}$ & $\begin{array}{c}\text { Technical } \\
\text { weight }\end{array}$ & Nokia & Samsung & $\begin{array}{c}\text { Company } \\
\text { Micromax }\end{array}$ \\
\hline TR1 & 54 & 5 & 9 & 5 \\
\hline
\end{tabular}

\begin{tabular}{|c|c|c|c|c|}
\hline TR2 & 37 & 5 & 5 & 9 \\
\hline TR3 & 69 & 9 & 9 & 9 \\
\hline TR4 & 31 & 1 & 9 & 3 \\
\hline TR5 & 36 & & 5 & 3 \\
\hline TR6 & 18 & & 5 & 5 \\
\hline TR7 & 27 & 5 & 5 & 5 \\
\hline TR8 & 45 & 3 & 9 & 9 \\
\hline Weight & & 1377 & 2381 & 2055 \\
\hline
\end{tabular}

weights

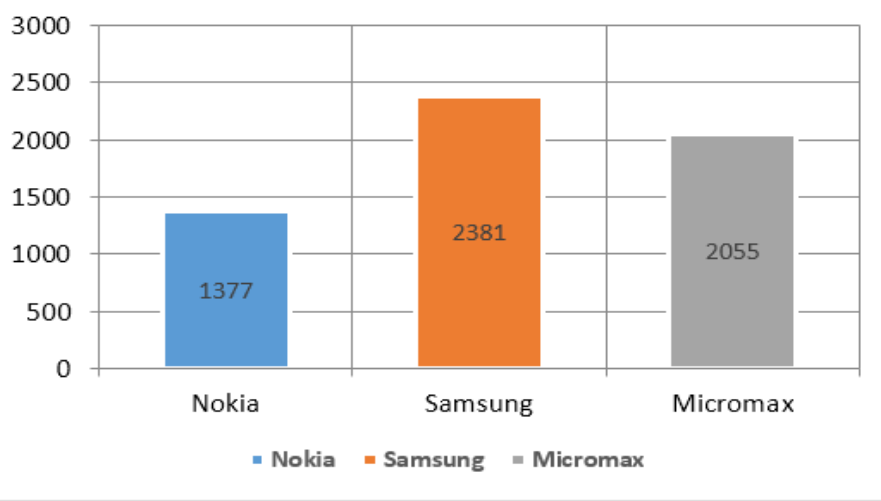

Fig- 4 Weights score of different brand mobile

Now an example of the suitable mobile of different brand within the range of 1000-4000 which meet nearly the above customer requirement as shown above in Fig- 4

\section{RESULTS AND CONCLUSIONS}

In this present work, QFD approach has been used for selecting a suitable mobile with different brand of mobiles for the common people taking cost as constraints. A real life case study was taken to prove the proposed methodology, in which customer requirements are taken as input and corresponding technical requirements are taken as output. Further, inter relationship matrix was generated as well as corresponding technical weights are computed. Finally, comparison of different mobile brands with the technical weights obtained by QFD matrix for selection of suitable mobile for common people. The results are tabulated in Table.5.In present mobile industry introducing variety of mobile into the market with a different feature and application.

\section{REFERENCES}

[1] Bayraktar, E., Tatoylu, E., Turkyilmaz,A., Delen, D., Zaim, S. 2012. Measuring the efficient of customer satisfaction and loyalty for mobile phone brand with DEA; Expert Systems with Applications.39: 99-106.

[2] Bevilacqua, M., Ciarapica, F.E., Giacchetta, G. A.2006. Fuzzy QFD approach to supplier selection journal of 
purchasing and supply management; Journal of purchasing and supply management. Vol.12: 14-27.

[3] Bhattacharya, A., Sarkar, B., 2007.Integrating AHP with QFD for robot selection under requirement perspective; International journal of production reaserch.vol. 43: No.17: 3671-3685.

[4] Chun, J., Sung, H.H., Hyunsuk, I., Park, Yongs S., 2011. A method for searching photos on mobile phone by using the fisheye view technique; International Journal of Industrial Ergonomics. 41: 280-288.

[5] Rajesh.G., Malliya, P., 2013.Supplier selection based on AHP QFD methodology; Procedia Engineering. Vol-64:1283-1292.

[6] Ha, S.H., Krishnan, R., 2008. A hybrid approach to supplier selection for the maintenance of competitive supply chain; Expert system with application; 34:13031311.

[7] Hong, W.C., Dong, Y., Chen, L.Y., Lai, C.Y., 2010. Taiwanese 3G mobile phone demand forecasting by SVR with hybrid evolutionary algorithms; Expert Systems with Applications. 37:4452-4462

[8] Isiklar, G., Buyukozkan G., 2007. Using a multi criteria decision making approach to evaluate mobile phone alternatives. Computer standards and interface; Computer Standards \& Interfaces. 29:265-274.

[9] Khoury, E., Shafey, L. E I., McCool, C., Gunther, M., Marcel, S., 2013. Bi-model biometric authentication on mobile phones in challenging conditions; Image and Vision Computing. IMAVIS-03270; No of Pages 14

[10] Oh, J., Choi, Sang-II., kim, C., Cho, J., Choi, C.H., 2013. Selective generation of Gabor feature for fast face recognition on mobile device; Pattern Recognition Letters. 34: 1540-1547.

[11] Prasad, k., Chakraborty, S., 2013. A quality function deployment based model for material selection; Material and design.49: 525-535

[12] Venkata Rao R., 2006. A material selection model using graph theory and matrix approach; Materials Science and Engineering A .431: 248-55.

[13] Wang, C.H., Chen, J.N., 2012. Using quality function deployment for collaborative product design and optimal selection of module mix; computer and industrial engineering. 63:1030-1037.

[14] Xu, X., Xiaolong, Z., Fu, H., Chen, L., Zhang, H., Fu, X., 2013. Robust passive autofocus system for mobile phone camera application; Computers and Electrical Engineering.

[15] Zheng, X., Pulli, P., 2007. Improving mobile service design QFD approach; Computing and Informatics.vol26: $369-381$. 